\title{
Philosophical Establishment Of Regional Regulations Based On Regional Characteristics
}

\author{
Victor Juzuf Sedubun \\ Faculty of Law Pattimura University, Ambon, Indonesia \\ e-mail:V.J.Sedubun@gmail.com
}

\begin{abstract}
Article 18B The 1945 Constitution of the Republic of Indonesia recognizes and respects the traditional rights of indigenous community. Article Number 14 of Law Number 12 Year 2011 in conjunction with Article Number 236 paragraph four (4) of Law Number 23 Year 2014 guarantees the formation of Regional Regulations based on regional characteristic. It is a normative research, using the approach of legislation and conceptual approach. It is necessary to amend Law No. 23 of 2014, especially in relation to the formation of Regional Regulations based on regional characteristics. Law Number 32 Year 2004 along with its implementing regulations and Law Number 23 Year 2014 do not specify the rules for the establishment of Regional Regulations based on regional characteristics.
\end{abstract}

Keywords: Philosophical, Local Regulations, Regional Characteristics

\section{INTRODUCTION}

The delegation of authority in the decentralization of state administration results in the permanent transfer of authority of the Government. The government loses the authority it has delegated and transfers to the party receiving the delegation of authority. In the perspective of state administration, decentralization is a delegation of central government power to regions to take care of their own households (autonomous regions). Decentralization is also a way or system for realizing the principle of democracy that provides an opportunity for the people to participate in the process of organizing the state government.

Regional autonomy cannot be interpreted as a freedom, meaningful autonomy of limited freedom or independence is a form of provision of opportunities that must be accounted for. Autonomy is free to determine what is best for itself. In that connection, 
regional autonomy can be understood as the regional autonomy to manage and manage their household life.

The implementation of local government based on the principle of decentralization is intended to provide wider opportunities for regions to manage and manage their households so that the goal of decentralization, namely the improvement of living standards in the region can be achieved. The state as an organization must be subject to the philosophy and organizational mechanism as a system. To realize the goals of the state required the arrangement of state organizations that are divided horizontally and vertically.

The history of the Indonesian administration shows the change of governance arrangements in the regions in the legislation. The horizontal sharing of power within the State of the Republic of Indonesia will be seen from the authority of each state institution that exercises state power in the legislative, executive and judicial fields as stipulated in the 1945 Constitution of the Republic of Indonesia. The administration of regional government in the context of a unitary state cannot be separated from the system of distribution power vertically based on Article 18 of the 1945 Constitution of the State of the Republic of Indonesia. The system of power-sharing vertically also affects the authority of the formation of regional legislation. Therefore, it is necessary to study the philosophy of giving authority to the formation of Regional Regulations to the regions, in the context of a unitary state.

The Second Amendment of the 1945 Constitution of the Republic of Indonesia resulted in the addition of Article 18 to become Article 18A, and Article 18B. Article 18 paragraph (1), paragraph (2), paragraph (5) and paragraph (6) confirm that:

(1) The Unitary State of the Republic of Indonesia shall be divided into provinces and provinces divided into districts and municipalities, each of which the provinces, districts and municipalities have local government, which is regulated by law.

(2) The provincial, regency, and municipal governments shall administer and manage their own governmental affairs according to the principle of autonomy and coadministration.

(3) The regional government shall exercise autonomy to the maximum extent, except for government affairs which by law are determined as the affairs of the Central Government.

(4) The regional government shall have the right to enact local regulations and other regulations to implement autonomy and assistance tasks.

Article 18 of the 1945 Constitution of the Republic of Indonesia becomes the basis of the constitutionality of regional government administration in Indonesia, including the authority to enact Local Regulations. Although the regions have been granted the right to 
establish Regional Regulations and other regulations in the context of implementing regional autonomy pursuant to Article 18 Paragraph (6) of the 1945 Constitution and the Co-Administration, this does not mean that the Regional Government can make regulations beyond the authority granted, so that regulations are established, contrary to the principles of the unitary state and the 1945 Constitution of the Republic of Indonesia. The Constitution provides the attributive authority to the regions to establish the Regional Regulations and other regulations. Local Regulations are expected to support the implementation of governance in the region, especially in the improvement of regional development.

\section{Problems}

Based on the background described above, then the problems raised are: What is the philosophy of Regional Government given the authority to configurate a Regional Regulation based on regional characteristic?

\section{Research Purposes}

The purpose of this research is to analyze and find the philosophical basis of the region given the authority to configurate a Regional Regulation based on regional characteristic?

\section{METHODS}

Legal science as a science that has a special character (sui generis discipline ${ }^{l}$ ) .Therefore the type of research used is normative research, to examine the provisions of positive law and legal principles, explain and estimate the direction of legal development in the future. The approach used in this research is statute approach and conceptual approach. Primary legal materials and secondary legal materials that have been collected (inventory), then grouped. The next step is to conduct an assessment with the legislative approach to obtain an overview of the synchronization of all legal materials. Legal material that has been classified and dis-systematically studied, studied and compared with legal theories and principles put forward by experts, to finally be analyzed normatively. The

${ }^{1}$ Philipus M. Hadjon, Legal Studies, Training Papers Normative Legal Research Methods, Research and Development Center of Law - Research Institute of Airlangga University in cooperation with the Faculty of Law Airlangga University, 11-12 June 1997, p. 1. 
results of the analysis are arguments to provide a prescription as a solution to the problem being analyzed.

\section{RESULTS AND DISCUSSION}

\section{The Essence of Regional Regulation based on regional characteristic.}

Existing freedom is not necessarily freedom without thinking of members of society.

Supposing a family household, then in carrying out the duties and functions as head of the family, the head of the family should pay attention to the comfort, needs and opinions of other family members. There should be restrictions on family relationships. In addition, there must also be restrictions that govern the association between family one with another family. So that created order and order of life, not only in the family but also with neighbors in the environment. The concept of real and responsible autonomy aims to improve service to the community.

Therefore, the formation of the law must be based on the truth of the facts that occur in society. Based on the truth of the fact the formation of the law must be able to meet the needs of the community against a certain rule that controls the behavior of individuals in society. Geoffrey Samuel ${ }^{2}$ points out that:

"The object of legal science is the constructed legal model of facts. The idea that the way facts are constructed internally leading to the way that they are thus viewed, is capable of creating a normative dimension quite separate from any normative aspect attaching to a legal rule. This fact construction can be seen as a kind of precategorisation before the facts are formally assigned to an established legal category. How facts are actually constructed at this precategorisation stage might well be an active step in the process of reaching a solution in a case and thus the construction - and reconstruction - of facts is as important as any search for, or an application of, a rule. The facts of a case are not real facts. They are not real-life situations, but are virtual fact because the object of legal science is not the phenomena of the real world (real facts of a case)."

Roscoe Pound ${ }^{3}$ points out that:

"There are two kinds of needs that have driven philosophical thinking about law. On the one hand, the great public need for public security, which as a necessity of peace and order dictates the origin of the law, has prompted humans to seek a definite foundation of a certain rule of human action that can contain arbitrary action - the authority of both the judge and the individual, to finally establish a firm and steady society. On the other hand the pressures of the less urgent public interest and the need to adapt them to the needs of

\footnotetext{
${ }^{2}$ Geofferey Samuel, Epistimology and Method in Law, Kent Law School, UK, Juridishe Bibliotheek University Utrecht, 2007, p. 175.

${ }^{3}$ Roscoe Pound, An Introduction to the Philosophy of Law, Translated from an expanded edition by Mohamad Radjab, Bhratara Karya Aksara, Jakarta, 1982, p. 54.
} 
the public security sector and to ceaselessly make new compromises because of constant change in society have always required adjustment-adjustment, at least about the details of the composition of society. "

The essence of the Regional Regulation that accommodates the interests of the people in the region in order to achieve the greatest happiness to the community must be respected by the central government as the government's affairs in the region in seeking the happiness and prosperity of the people in the region. With such acknowledgment, the regions have the right to enact Local Regulations to accommodate the special conditions of the region and to organize the community life in their area in the inter-individual relationship. The central government can no longer intervene in the formation of a Regional Regulation, although the content of the Regional Regulations established by the local government authorities is contradicted by the higher regulation unless the material mutant conflicts with the constitution, the law and the purpose of the formulation of the Regional Regulation itself.

The ideology of law (rechtsidee) implies that in essence the law as a rule of community behavior is rooted in the ideas, tastes, intentions, ideas, and thoughts of the community itself. Thus, the ideals of the law are ideas, intentions, inventions and thoughts dealing with the law or perception of the meaning of the law, which essentially consists of three elements, namely: justice, doelmatigheid and legal certainty ${ }^{4}$.

According to Eugen Ehrlich, positive law can have effective power if harmonized with living law and those who act, as legal advocates must have a close relationship with the values held in the community ${ }^{5}$. The central point of legal development lies not in the law, judgment, or legal science, but rather in the society itself.

Involvement means engaging the community and all parties to actively think about the issues at hand and together to find the best solution for all of them. Including such a society is one way of obtaining substance from the public interest. The process of forming such a law will make the law not only a tool for holding power, but it is also functional in the interests of the people ${ }^{6}$.

\footnotetext{
${ }^{4}$ Bernard Arief Sidharta, Reflection on the Structure of Legal Science, Mandar Maju, Bandung, 2009, p. $180-181$.

${ }^{5}$ Eugen Ehrlich in Darji Darmodiharjo and Shidarta, Principal Principles of Legal Philosophy, What and How Indonesian Law Philosophy, Gramedia Pustaka Utama, Jakarta, p. 128-130.

${ }^{6}$ Bagir Manan I, Authoritative Judicial System: A Search. The Supreme Court of the Republic of Indonesia, Jakarta, 2004, p. 5.
} 
According to Bernard L. Tanya, in the formulation of legislation, it is necessary to consider the principles of morality. These principles can also be applied in the formation of Regional Regulations. It is argued that:

"The objective of law based on the ideology of Pancasila is to provide human protection, ie to protect human beings passively by preventing arbitrary actions, and actively (positively) by creating humane conditions of society which enable the process of society to proceed fairly, it is fair for every human being to have an equal and equal opportunity to develop all of his human potential as a whole ${ }^{7 "}$

This includes the philosophical views of the nation embodied in the motto of Bhinneka Tunggal Ika, "Unity in Differences and Differences in Unity" because in that phrase it implies the recognition and respect for human dignity, the distinctiveness of the existing ethnic/ethnic groups in the life of nation and state.

The formation of a Regional Regulation should accommodate the views of life, cultural values, and justice and can be a means to create and maintain order, stability, and predictability. It can also be a means of preserving cultural values, education, community civilization, and community renewal. Protection of traditional knowledge is important, considering that to date many local governments have not yet protected the traditional knowledge of their respective regions. The harmony between the living law in society and the resulting positive law. This alignment will ensure the effective enforceability of the positive law in society. Thus, the cultural values that are characteristic of each region are manifested in the formulation of laws and regulations, especially Regional Regulations that are characterized by the regions and become one of the test instruments against Regional Regulations that are based on region characteristic.

\section{Regional Regulation Based on Regional Characteristics according to the $\mathbf{1 9 4 5}$ Constitution of the State of the Republic of Indonesia.}

The regulation of Article 18 Paragraph (1) of the 1945 Constitution of the Republic of Indonesia is a consequence of the understanding of Article 1 Paragraph (1) of the NRI Constitution of 1945. It is also understandable if we look at the Elucidation of Article 18 of the 1945 Constitution which states that:

"Since the Indonesian state is an eenheidsstaat, then Indonesia will not have the Region in its staat environment as well. The Indonesian territory will be divided into 5.

\footnotetext{
${ }^{7}$ Bernad L. Tanya and Yovita A. Mangesti, Legal Morality, Genta Publishing, Yogyakarta, 2014, p.
} 
Provincial and Provincial Areas to be divided into smaller areas. In autonomous regions (streek en locale rechtgemeenschappen) or mere administrative nature, all according to the rules to be established by law ". In regions that are autonomous will be held Regional Representative Body. Therefore, in any area, the government will juxtapose on the basis of deliberation.

The Autonomous Region referred to in the Elucidation of Article 18 of the 1945 Constitution is conceived as a Regional Government consisting of "large area" and "small area". In addition, in addition to being an autonomous region, such areas may also be administrative or autonomous regions of a special nature. Against the special autonomous region, in the Elucidation of Article 18 of the 1945 Constitution is called Zelfbesturende landschappen and Volksgemeenschappen which at that time mentioned the number in Indonesia of approximately 250 regions.

Related to the statement above, Soegeng Istanto $^{8}$ put forward the following conclusions:

a. The area is not staat;

b. The territory of Indonesia will first be divided into these provinces and provinces and then subdivided into smaller areas;

c. This area may be autonomous and may also be administrative;

d. In the autonomous regions, the Regional Representative Body shall be established in accordance with the foundation of deliberation in the system of state government.

The municipality and the provincial government are granted the freedom to administer and regulate local household affairs. Provincial and municipal governments act freely for the local interest of each region within the territory of the area. Local Government acts in accordance with the authority granted by law.

The Regional Government that provides for the people of the region in accordance with the needs and special conditions in the region, as long as it can still be accounted for by Local Governments Local Governments who know more and understand the needs of people in the region. Thus, the Regional Government should be given the authority to form a Regional Regulation, not just to enact a Regional Regulation.

Article 18 paragraph (6) of the 1945 Constitution of the Republic of Indonesia also does not mention which organs are authorized to establish a Regional Regulation. The Regional Government is granted the authority of attribution to establish a Regional

\footnotetext{
${ }^{8}$ F. X. Soegeng Istanto, Several Facets of Central and Regional Government Relations within the Unitary State of Indonesia, Faculty of Social and Political UGM, Yogyakarta, 1968, p. 22.
} 
Regulation, in which the authority of attribution is the authority available to the position in office ${ }^{9}$.

In addition, Jimly Asshiddiqie also expressed his opinion on the understanding of government. Jimly Asshiddiqie ${ }^{10}$ states that:

"Governance is defined as the process of government or the whole system and mechanism of government. Thus the word government is narrower in terms of understanding that the government. The word government can be said to refer only to executing or executive institutions only in order to implement central and regional legislation that contains state policy in the region and local government policy itself. The function of the executive or the executive is actually historically related to the function of implementing the rules containing the normative rules, either in the form of general rules or in the form of the policy rule (beleid-regels). The General Rules may be in the form of regulations stipulated in the form of central legislation and may also be stipulated in the form of regional regulations or other regulations as referred to in Article 18 Paragraph (6) of the 1945 Constitution of the Republic of Indonesia.

Related to the term "government", it is necessary to express the opinion of Tatiek Sri Djatmiati11 ${ }^{11}$ stating that: "The 1945 Constitution distinguishes the term Government and Government by emphasizing on the meaning of institutions (bodies) and functions of government (government)". This opinion means that the term "government" refers to an institution (organ/body) that performs tasks in the field of Government, while "Government" refers to operational and functional aspects.

The autonomous region according to Bagir Manan ${ }^{12}$, as an independent government with attributive authority-moreover as a legal subject (publiek rechtpersoon, public legal entity) - is authorized to make regulations to administer its household. The authority of this regulation exists on the Regional Government (state administrative officials) and the DPRD as the holder of legislative functions in the regions. Regional Regulation is the implementation of the legislative function of DPRD.

9 Tatiek Sri Djatmiati, et al, Law Administration and Good Governance, Publisher Universitas Trisakti, Jakarta, 2010, p. 20-21

${ }^{10}$ Jimly Asshiddiqie I, Consolidation of the 1945 Constitution After the Fourth Amendment, Center for the Study of Constitutional Law Faculty of Law University of Indonesia, Jakarta, 2002, p. 21. See also in Sukardi. Cancellation of Local Regulations and Their Legal Effects. Dissertation. Postgraduate Program of Airlangga University. Surabaya. 2009. h. 72.

11 Tatiek Sri Djatmiati, Principles of Industrial Business License in Indonesia, Dissertation, Postgraduate Program of Airlangga University, Surabaya, 2004, p. 44.

${ }^{12}$ Bagir Manan II, Theory and Politics of the Constitution, (Bagir Manan III), FH UII Press, Yogyakarta, 2004, p. 71. 
The above statement is in line with the opinion expressed by Jimly Asshiddiqie ${ }^{\mathbf{1 3}}$ stating that:

"... In accordance with its level, the institutions and officials who are entitled to make the rules should be limited only to parliamentary institutions together with officials holding political positions, not those holding positions as government employees. Parliamentary institutions in question at the level are the center of House of Representatives, Regional People's Representative Assembly , and Regency / Regional People's Representative Assembly which are the representative bodies of the people. "

Related with this, it can be argued that the authority of the Regional Government in Scotland, as stated by Gérard Marcou ${ }^{\mathbf{1 4}}$ that:

"The powers and functions exercised by local authorities are conferred on them by law. Any measure taken outside these limits is ultra vires and therefore illegal. This traditional principle, which was confirmed by the 1972 Act, stems from the principle of the sovereignty of Parliament. It has been eased in various ways, first by the 1972 Act itself, which allows local authorities to do anything which, to a reasonable extent, facilitates or is conducive to the discharge of their functions (section 111).

Secondly - and above all - the Local Government Act 2000 (and the equivalent Scottish legislation in Scotland) empowers all local authorities to do anything which they consider likely to promote "the economic, social and environmental well-being" of their area (section 2)."

Based on the opinion of Tatiek Sri Djatmiati, Bagir Manan, Jimly Asshiddiqie, Febrian and Gérard Marcou above, there is a similarity that the formation of a Regional Regulation is the authority of the parliamentary institution both at the center and in the region, in this case, the DPRD. The authority of the regional head, -as the President at the center of the draft law, is to propose a draft of a Regional Regulation. Furthermore, the Head of Region discussed the draft of Regional Regulation to reach an agreement.

The formation of Regional Regulations should be able to involve the participation of the community, especially in providing input, both oral and written in the preparation stage of the draft of the Regional Regulation up to the stages of the discussion of the draft of the Regional Regulation. Thus, the DPRD should be given authority in the formation of Regional Regulations. Head of Region may propose the Regional Regulation of Initiative, then the Head of Region together with DPRD shall discuss the draft of Local Regulation for approval and subsequently, the Regional Head shall approve the draft of Regional

\footnotetext{
${ }^{13}$ Jimly Asshiddiqie II, Constitution and Constitutionalism, (Jimly Asshiddiqie I), Constitution Press, Jakarta, 2005, p. 247-248.

14 Gérard Marcou, Gérard Marcou, "Local authority competences in Europe". accessed from https://wcd.coe.int/ViewDoc.jsp?id=1377639\#P1203_137282, on February 19, 2015, p. 73.
} 
Regulation which has been approved to become a Regional Regulation. This is in accordance with Article 18 paragraph (6) of the 1945 Constitution of the Republic of Indonesia.

Another difficulty that arises is related to the presence or absence of a pinhead in the 1945 Constitution of the State of the Republic of Indonesia which guarantees the formation of Regional Regulations that are characteristic or special conditions of the region. "

Solving the above difficulties, it is necessary to be associated with the provisions of Article 18B of the 1945 Constitution of the Republic of Indonesia states that:

(1) The State acknowledges and respects local government units of a special or special nature regulated by law.

(2) The State recognizes and respects the unity of indigenous and tribal peoples along with their traditional rights as long as they are alive and in accordance with the development of society and the principle of the Unitary State of the Republic of Indonesia, as governed by law.

The provisions of Article 18B paragraph (1) of the 1945 Constitution of the Republic of Indonesia supports the existence of various special or special government units (both provinces, districts and cities, and villages). Examples of special government units are the Jakarta Special Capital Region (DKI); examples of special government units are the Special Territories (DI) of Yogyakarta and the Special Territory (DI) of Nangroe Aceh Darussalam (NAD). As for the provisions of Article 18B paragraph (2), it is then known that there are government units at the village level such as gampong (in NAD), nagari (in West Sumatra), dukuh (in Java), villages and banjars (in Bali) and various groups communities in different regions live according to customs with their rights such as customary rights, but on the condition that indigenous and tribal peoples exist and are not forced to exist and not alive. Therefore, in its implementation, the group must be further regulated in the Regional Regulations set by the DPRD. In addition, the designation is of course with a limitation, that is, it should not be contrary to the principles of a unitary state.

The provision of Article 18B paragraph (1) according to Jimly Asshiddiqie ${ }^{15}$ is that: "The 1945 Constitution itself recognizes the existence of special or special government units, including if the regional government structure in question has a specificity (italics by the authors) in the regulation of the position of the governor attributed to certain breeds concretely with the mention which is 'personal' as the subject of special state law. "

\footnotetext{
${ }^{15}$ Jimly Asshiddiqie III, Subject to Law, Constitution Press, Jakart, 2006, p. 22.
} 
The above statement of Jimly Asshiddiqie, especially on the part which is skewed by the author, includes also the definition of the specificity held by the community in a particular area whose specificity is not specifically regulated in a separate law. It means that in all regions having special characteristics and special conditions which are still alive and not contradictory to the principle of the Unitary State of the Republic of Indonesia, shall be entitled to be recognized by the Government and may be protected by the Regional Government through the establishment of a Regional Regulation.

The existence of state recognition and respect for the unity of indigenous and tribal peoples as long as they are alive and in accordance with the development of society and the principle of the Unitary State of the Republic of Indonesia, illustrates that a country in which there is a Regional Government established by the state recognizes and respects unity indigenous and tribal peoples and their traditional rights. The traditional rights of indigenous and tribal peoples also include the local wisdom of the customary law community unity itself.

According to the provisions of Article 18B of the 1945 Constitution of the Republic of Indonesia, the Regional Government in establishing the Regional Regulation should pay attention and accommodate the protection of the traditional rights of customary law community unity in its area. Because the traditional rights that exist in each region has formed and incarnated in local customs and local wisdom. So the area has special characteristics and/or special conditions attached to the area and it also contributes to the difference between one areas with other areas.

In relation to the authority of regional governments to enact Regional Regulations as stipulated in the provisions of Article 18 Paragraph (6) of the 1945 Constitution of the Republic of Indonesia, based on the provisions of Article 18B of the 1945 Constitution of the Republic of Indonesia of 1945 which recognizes and respects the unity of indigenous and tribal peoples, Areas that are based on special characteristics and / or special conditions of each region. The 1945 Constitution of Republic of Indonesia, provides an opportunity for the Region to establish a Regional Regulation based on special characteristics and/or special conditions that are rooted in the life of the people in the region with due regard to the development and principles of the Unitary State of Indonesia.

The content of Regional Regulations that are characterized by the regions are not included in the details of the distribution of government affairs between the Government, 
Provincial Government and Regency/City Government as contained in Attachment to Government Regulation Number 38 Year 2007 on the Division of Government Affairs between the Government, Provincial Government and District / hereinafter referred to as PP Number 38 Year 2007). To that end, the Regional Government may propose the authority of the formation of Regional Regulations that characterize the regions of the Government for a determination.

\section{Regional Regulation Based on Regional Characteristics in Law Number 12 Year 2011 and Law Number 23 Year 2014}

According to the authority of the formation of a Regional Regulation, Law No. 12 recognizes Regional Regulation as one type of legislation that has a position in the hierarchy of laws and regulations. Article 7 of Law Number 12 Year 2011 which regulates the type, hierarchy, and content of statutory content states that:

(1) The type and hierarchy of legislation consist of:

a. 1945 Constitution of the State of the Republic of Indonesia;

b. Decision of the People's Consultative Assembly;

c. Law / Government Regulation in Lieu of Law;

d. Government regulations;

e. Presidential decree;

f. Provincial Regulations; and

g. Regency / City Regulations.

(2) The legal power of the Legislation shall be in accordance with the hierarchy as referred to in paragraph (1).

The position of Regional Regulation based on the provisions of Article 7 paragraph (1) of Law Number 12 Year consists of Provincial Regulations and Regency/City Regulations. This consequence affects the content of the Regional Regulations at each level. It means that based on the principle of the formation of legislation in the provisions of Article 5 of Law Number 12 Year 2011, the lower legislation of its status shall not be contrary to the higher regulations. Consequences that arise is the content material of Regency/City Regulation shall not be contradictory to Provincial Regulation.

The authority of the formation of Regional Regulation based on the characteristic, then Article 14 of Law Number 12 Year 2011 states that:

The content of the Provincial Regulations and the Regency/City Regulations shall contain the content material in the context of the implementation of regional autonomy and coadministration tasks and accommodate the special conditions of the region and/or further elaboration of the higher Laws Regulations. 
Arrangement of Article 14 of Law Number 12 Year 2011 above, especially regarding the phrase "Content of Provincial Regulations and Regency/Municipal Regulations contains content in the framework of the implementation of regional autonomy and duty of assistance and accommodate special conditions of the region .......", when associated with the provision of Article 18B paragraph (2) of the 1945 Constitution of the Republic of Indonesia, gives meaning that the content of Regional Regulations established by the Regional Government can regulate the characteristics possessed by their respective regions. The phrase "to acknowledge and respect" indicates that the unity of indigenous and tribal peoples (including those characteristics of each tribe) is recognized and respected by the state.

The absence of standardized criteria of regional characteristics contains the consequence that each region may demand a specificity, solely on the basis of certain factors without a general criterion established by law. Especially if the specificity contains a certain charge of privilege that is not owned by other regions.

Regional Government under the provisions of Article 1 Sub-Article 2 of Law Number 23 Year 2014 which states that:

"Regional government is the administration of government affairs by the regional government and the regional legislature according to the principle of autonomy and duty of assistance with the principle of autonomy as wide as possible in the system and the principle of the Unitary State of the Republic of Indonesia as referred to in the 1945 Constitution of the Republic of Indonesia."

The provision of Article 1 Sub-Article 2 above means that the regional government consists of the regional government and the DPRD that administers government affairs. The local government in question is the Governor as the head of the provincial region as well as the representative of the central government and the Regent/Mayor as the head of regency/municipality.

Regional Regulation is a demand for a relationship between the center and the region in the form of a unitary state based on the principle of autonomy. Implementation of the local government by elaborating the provisions in the legislation requires the provision of Regional Regulations in accordance with the potential and diversity of the region. In relation to Regional Regulations in accordance with the potential and diversity of regions, as regulated in Article 236 paragraph (4) of Law Number 23 Year 2014. 
A general explanation of the number 8 of Law Number 23 Year 2014 states as follows:

"In executing Government Affairs which is the authority of the Region, the regional head and the Regional People's Legislative Assembly as the Regional Government Authority shall make the Regional Regulation as the legal basis for the Region in organizing Regional Autonomy in accordance with the condition and aspirations of the people and the peculiarities of the Region. Regional Regulations made by the Regions shall only apply within the limits of the jurisdiction of the Region concerned. Nevertheless, the Regional Regulations stipulated by the Regions shall not be contradictory to the provisions of laws and regulations that are higher in accordance with the hierarchy of laws and regulations. In addition, the Regional Regulation as part of the legislative system should not conflict with the public interest as stipulated in the rules of drafting the Regional Regulation. "

The provision of Article 236 paragraph (4) of Law Number 23 Year 2014 is the basis of the legal action for the Regional Government to form a Regional Regulation which is characterized by the region by observing the principles of the Unitary State of the Republic of Indonesia. This is reinforced by the general explanation of the number 8 of Act No. 23 of 2014 which recognizes the existence of the formation of Regional Regulations that are characteristic of their respective regions, as long as the Regional Regulations established are only valid in the jurisdiction of the region concerned.

The change of the characteristic of "nomenclature" in Law Number 32 Year 2004 to "local" in Law Number 23 Year 2014, can be argued that the nomenclature of "local content material" as used in Law Number 23 Year 2014 has a broader meaning compared to the nomenclature " characteristic "and" special conditions "used in Law Number 32 Year 2004 and Act Number 12 Year 2011. Something that is local in nature contained in it the peculiarities and peculiarities possessed by a region. A general explanation of the number 8 of Law Number 23 Year 2014 also recognizes the uniqueness of regions that can be accommodated in the content of the content of Regional Regulations.

\section{Formation of Regional Regulations Based on Regional Characteristics According to the Regulation of the Minister of Home Affairs Number 1 Year 2014 on Products of Regional Law .}

Regulation of the Minister of Home Affairs Number 1 Year 2014 technically regulates the establishment and supervision of local legal products. The regional legal products referred to in the Regulation of the Minister of Home Affairs Number 1 year 2014 include legal products of regulatory and determinative nature. Article 3 Regulation of the Minister of Home Affairs Number 1 Year 2014 states that: 
"The legal products referred to in Article 2 letter a shall be in the form of:

a. Regional Regulations or other names;

b. PB; and

c. Regulations of Regional People's Representative Assembly "

The arrangement of Regulations of Regional People's Representative Assembly as part of local law product is new because Regulation of the Minister of Home Affairs Number 53 Year 2011 does not recognize the existence of Regulation of the Minister of Home Affairs Regulation as local law product.

The positioning, hierarchy, and content of the Regional Regulation shall be stipulated in Regulation of the Minister of Home Affairs Article 4 of Number 1 Year 2014 which states:

(1) The Regional Regulation as referred to in Article 3 letter a shall consist of:

a. Provincial Regulations; and

b. Regulation of regency/municipality

(2) Provincial Regulations as referred to in paragraph (1) sub-paragraph a have a higher hierarchy than Regency / Municipal Regulations;

(3) Provincial Regulations as referred to in paragraph (1) letter a shall contain content to regulate provincial authority and/or may regulate district/city authorities.

(4) Provincial Regulation as referred to in paragraph (3) may regulate the authority of regency/municipality if there are arrangements related to the content of districts/cities.

The arrangement of Article 4 regulation of minister of home affair Number 1 Year 2014 indicates that the position of Provincial Regulation is higher than Regency / City Regulation. The content of the Provincial Regulations shall regulate the authority of the province and/or may regulate the authority of the $\mathrm{f}$ if there is an arrangement concerning the content related to the district/city. Regulation of the Minister of Home Affairs Number 1 Year 2014 does not clearly regulate the content of Regency / City Regulations.

This lack of clarity creates difficulties associated with the authority of the district/municipal governments in formulating Regional Regulations whose material content regulates the characteristics of the regions.

In relation to the implementation of governance in the regions, the task of the government is to provide services and provide for the people of the region what the needs of its people. This includes providing protection and respect for the special conditions and characteristics possessed by the region, whether in the form of protection and respect for traditional rights as well as local wisdom in the region. 
The local government of regency/municipality based on the authority as regulated in Article 18B of the 1945 Constitution of the Republic of Indonesia, Article 236 paragraph (4) of Law Number 23 Year 2014 and Article 14 of Law Number 12 Year 2011, may form a Regional Regulation whose content is based on regional characteristics. Load material on regional characteristics is permitted so far as to regulate traditional rights and local wisdom as long as traditional rights and local wisdom are not inconsistent with the constitution and the principle of the Unitary State of the Republic of Indonesia

The function of the Regional Regulation to administer the regulation as a further elaboration of the higher legislation with due regard to the characteristics of each Region is a further elaboration of the higher regulations or policies by lower government units and reflects the characteristics of the Regional Regulations as delegated legislation. M. P. Jain ${ }^{\mathbf{1 6}}$ states that the definition of delegated legislation is: "the subsidiary legislation itself made by the administration in pursuance of the power of delegated to it by the legislature" and "the exercise of the power by the agency".

According to M. P. Jain, the benefits of delegated legislation are as follows ${ }^{17}$ :

a. The modern state discharges multifarious functions; it has come to manage a large part of the socio-economic life of the people, this circumstance has created the need for more and more legislation. Law has become the instrument of social change.

b. A method to economize legislative time is delegated legislation. The legislature saves time by confining itself to broad principles in the law it enacts leaving the details to be formulated by the concerned administrative authorities. If Parliament were not willing to delegate law making power, Parliament would not be able to pass the kind and quantity of legislation which modern public opinion requires.

c. The truth is that the legislature would be subjected to an impossible load of work if it were to endeavor to enact legislation by itself complete in all details, so that it may concentrate on the essential principles and policies underlying a bill. As most of the present day legislation pertains to socio-economic matters, the details inevitably tend to become technical and complex and only professional experts specialized in the subject matter can work them out, rather than the legislators who are generalists and not specialists.

d. The system of delegated legislation has the advantage of flexibility, elasticity, expedition and experimentation. The technique of delegated legislation avoids such a situation and introduces flexibility. Delegated legislation fulfills the need of modern times that something less cumbrous and more expeditious than an Act of Parliament shall be available to amplify the main provisions, to meet unforeseen contingencies and to facilitate adjustment that may be called for after the scheme has been put into operation.

e. Finally, there is the need to meet emergency situations."

\footnotetext{
${ }^{16}$ In Sukardi, Op.cit., P. 45.

17 ibid
} 
The character of Regional Regulation as delegated legislation as stated A.W. Bradley and K.D. Ewing ${ }^{\mathbf{1 8}}$, above essentially stated that: "delegated legislation is an inevitable feature of modern government for reasons.

a. Pressure on Parliament Time

b. Technicality of Subject Matter

c. The Need for Flexibility

d. State of Emergency."

The consequence of the principle of separation of the executive, legislative and judicial powers in the text of the First Amendment of the 1945 Constitution, the legislative product of this region may be contrary to the executive products at the central level. For example, if a matter of Provincial Regulations or District Regulations that have been legally stipulated contradict its contents with the Ministerial Regulation at the central level then the court must determine that the Regional Regulation is applicable throughout its territory. Ministerial Regulations are intended to be generally accepted throughout Indonesia.

The content of the Regional Regulation that takes into account the characteristics of the Region shall be carried out so that the Regional Regulation shall uphold the customs of the local community in which custom arises because of the forces behind the law which is always a social force that is customs. Customs arise because of the custom of the community to carry out its social activities, wherein the enforcement of social activities, it is necessary pressures that over time the customs accompanied by such pressure will be a rule that must be executed by the authorities so that the Regional Regulation becomes effective and have binding power in society, Local Regulations must always consider the customs of society where the enactment of the Regional Regulation.

\section{CONCLUSION}

\section{Conclusion}

Article 18B of the 1945 Constitution of the Republic of Indonesia is the constitutional basis of the authority of Regional Government to form a Regional Regulation that is characteristic of the region. States recognize and respect the traditional rights of indigenous and tribal peoples' communities. The formation of local regulations should accommodate the views of life, cultural values, and justice. Regional regulations that characterize a regions should be a means of creating and maintaining order, stability, predictability,

${ }^{18}$ A. W. Bradley and K. D. Ewing. Constitutional and Administrative Law. 13th edition. Pearson Education Limited. Essex. 2003., pp. 650-651 
means of preserving cultural values, education, community civilization, and community reform. Article 14 of Law Number 12 Year 2011 in conjunction with Article 236 paragraph (4) of Law Number 23 Year 2014 guarantees the formation of Regional Regulations that are peculiar to the regions and become a part for the Regional Government to establish Regional Regulations based on the regional characteristics by observing the principles of The Unitary State of the Republic of Indonesia. The nomenclature of "local content material" has a broader meaning compared to "typical" and "special conditions". Something that is local in nature contained in it the peculiarities and peculiarities possessed by a region.

\section{Suggestions}

The changes to legislation in local government need to be done to create good governance in the region. Completion is required in connection with the formation of Regional Regulations Based on Regional Characteristics as mandated in Article 18B paragraph (1) of the 1945 Constitution of the Republic of Indonesia, Law Number 32 year 2004 which replaced with Law Number 23 year 2014.

\section{BIBLIOGRAPHY}

[1] Asshiddiqie, Jimly. Consolidation of the 1945 Constitution After the Fourth Amendment. Center for Constitutional Law Studies Faculty of Law University of Indonesia. Jakarta. 2002.

. Constitution and Indonesian Constitutionalism. Constitution Press. Jakarta. 2005.

[3] 2006, Subject to Law, Constitution Press, Jakarta.

[4] Bradley, A. W., and K. D. Ewing. Constitutional and Administrative Law. 13th edition. Pearson Education Limited. Essex. 2003.

[5] Darmodiharjo, Darji, and Shidarta. Principal Principles of Legal Philosophy, What and How of Indonesian Law Philosophy. Gramedia Pustaka Utama. Jakarta. 2005.

[6] Djatmiati, Tatiek Sri. Principle of Industrial Business License in Indonesia. Dissertation. Postgraduate Program of Airlangga University. Surabaya. 2004.

[7] Djatmiati, Tatiek Sri, et. al. Administrative and Good Governance Law. Trisakti University Publisher. Jakarta. 2010.

[8] Gérard Marcou, "Local authority competences in Europe". accessed from https://wcd.coe.int/ViewDoc.jsp?id=1377639\#P1203_137282, on February 19, 2015.

[9] Hadjon, Philipus M. Legal Studies. Training Papers Normative Legal Research Methods, Research, and Development Center of Law - Research Institute of Airlangga 
University in collaboration with the Faculty of Law Airlangga University, 11-12 June 1997.

[10] Istanto, F. Soegeng. Some Centers of Central and Regional Government Relations within the Unitary State of Indonesia. Faculty of Social and Political UGM. Yogyakarta. 1968.

[11] Manan, Bagir. Theory and Politics of the Constitution. FH UII Press. Yogyakarta. 2003. the Republic of Indonesia. Jakarta. 2004.

[13] Pound, Roscoe. An Introduction to the Philosophy of Law. Translated from an expanded edition by Mohamad Radjab. Bhratara Karya Aksara. Jakarta.1982.

[14] Samuel, Geofferey. Epistemology and Method in Law. Kent Law School, UK, Juridishe Bibliotheek University Utrecht. 2007. 